\title{
The benthic infauna of the North Sea: species distribution and assemblages
}

\author{
A. Künitzer, D. Basford, J. A. Craeymeersch, \\ J. M. Dewarumez, J. Dörjes, G. C. A. Duineveld, \\ A. Eleftheriou, C. Heip, P. Herman, P. Kingston, \\ U. Niermann, E. Rachor, H. Rumohr, and \\ P. A. J. de Wilde
}

Künitzer, A. Basford, D., Craeymeersch, J. A., Dewarumez, J. M., Dörjes, J., Duineveld, G. C. A., Eleftheriou, A., Heip, C., Herman, P., Kingston, P., Niermann, U., Rachor, H., Rumohr, H., and de Wilde, P. A. J. 1992. The benthic infauna of the North Sea: species distribution and assemblages. - ICES J. mar. Sci., 49: 127-143.

In 1986 participants of the Benthos Ecology Working Group of ICES conducted a synoptic mapping of the infauna of the southern and central North Sea. Together with a mapping of the infauna of the northern North Sea by Eleftheriou and Basford (1989) this provides the database for the description of the benthic infauna of the whole North Sea in this paper. Division of the infauna into assemblages by TWINSPAN analysis separated northern assemblages from southern assemblages along the $70 \mathrm{~m}$ depth contour. Assemblages were further separated by the $30,50 \mathrm{~m}$ and $100 \mathrm{~m}$ depth contour as well as by the sediment type. In addition to widely distributed species, cold water species do not occur further south than the northern edge of the Dogger Bank, which corresponds to the $50 \mathrm{~m}$ depth contour. Warm water species were not found north of the $100 \mathrm{~m}$ depth contour. Some species occur on all types of sediment but most are restricted to a special sediment and therefore these species are limited in their distribution. The factors structuring species distributions and assemblages seem to be temperature, the influence of different water masses, e.g. Atlantic water, the type of sediment and the food supply to the benthos. Eleftheriou, A. and Basford, D. J. Journal of the Marine Biological Association of the UK, 69: 123-143.

Key words: benthos, North Sea, assemblages.

Received 21 March 1991; accepted 9 January 1992.

A. Künitzer: Alfred-Wegener-Institut für Polar- und Meeresforschung, Columbusstraße, D-2850 Bremerhaven, Germany. Present address: Umweltbundesamt, Bismarckplatz I, D1000 Berlin 33, Germany. D. Basford: Marine Laboratory, P.O. Box 101, Victoria Road, Aberdeen AB9 8DB. Scotland. J. A. Craeymeersch: Delta Instituut voor Hydrobiologisch Onderzoek, Vierstraat 28, NL-4401 EA Yerseke. The Netherlands. J. M. Dew'arumez: Station Marine, BP 41 Wimereux, F-62930, France. J. Dörjes: Institut für Meeresbiologie und Meeresgeologie "Senkenberg", Schleusenstr. 39A, D-2940 Wilhelmshaven, Germany. G. C. A. Duineveld \& P. A. J. de Wilde: Nederlands Instituut voor Onderzoek der Zee, P.O. Box 59, NL-1790 AB Den Burg/Texel, The Netherlands. A. Eleftheriou: Marine Laboratory, P.O. Box 101, Victoria Road, Aberdeen AB9 8DB. Scotland. Present address: Department of Biology, University of Crete, P.O. Box 1470. Heraklion 71110, Crete, Greece. C. Heip: Institut voor Dierkunde, Ledeganckstraat 35, B-9000 Gent, Belgium. Present address: Delta Instituut voor Hydrobiologisch Onderzoek, Vierstraat 28, NL-440I EA Yerseke, The Netherlands. P. Herman: Delta Instituut voor Hydrobiologisch Onderzoek, Vierstraat 28, NL-440I EA Yerseke, The Netherlands. P. Kingston: HeriotWatt University, Institute of Offshore Engineering, Research Park Riccarton, Edinburgh EH14 4AS, Scotland. U. Niermann: Biologische Anstalt Helgoland, Notkestr. 31, D-2000 Hamburg 52, Germany. E. Rachor Alfred-Wegener-Institut für Polar- und Meeresforschung, Columbusstraße, D-2850 Bremerhaven, Germany. H. Rumohr: Institut für Meereskunde, Düsternbrooker Weg 20, D-2300 Kiel, Germany.

\section{Introduction}

At the beginning of this century Petersen (1914) developed the concept of infaunal communities in order to describe and quantify areas with similar fish food. During the following 20 years several areas in the North Sea were investigated for their benthic infauna which were classified into certain communities or assemblages. Most of 


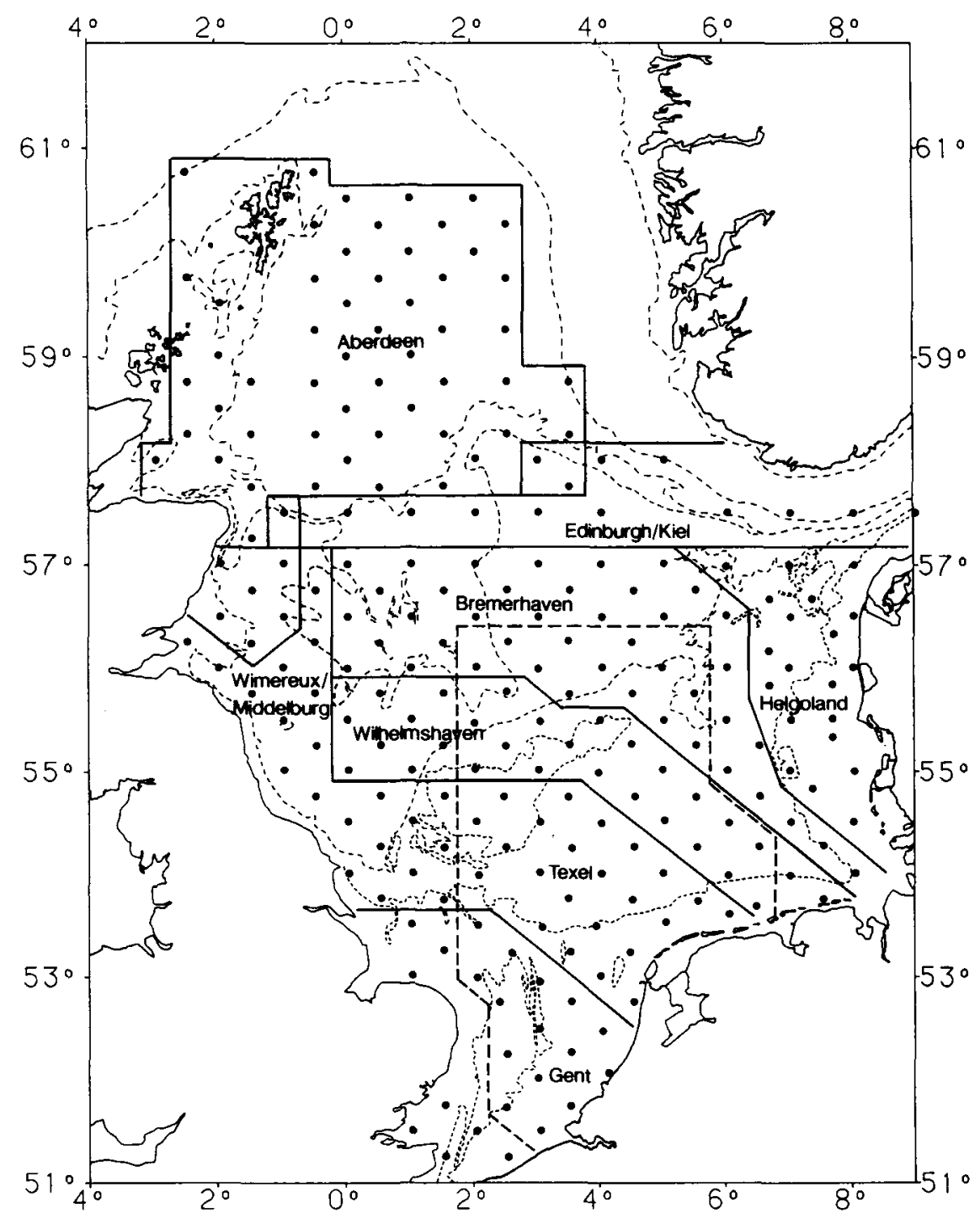

Figure 1. Stations sampled by participants of the North Sea Benthos Survey (NSBS) in 1986. Stations in the northern North Sea (Aberdeen) were sampled between 1980 and 1985.

these surveys were carried out in coastal areas, not further north than the Dogger Bank area. A review of the infaunal assemblages of the North Sea was given by Kingston and Rachor (1982), showing the low number of benthic surveys in the central and northern North Sea. Investigations in the vicinity of oil platforms suggested that infauna assemblages north of the Dogger Bank might be similar to those south of it. On the other hand, Glemarèc (1973) developed a concept of three different zones of benthic assemblages along the European North Atlantic Continental shelf, reflecting differences in annual variation of temperature in bottom waters. He divided the North Sea into three zones: the southern North Sea up to the northern edge of the Dogger Bank; the central North
Sea from 60 to $100 \mathrm{~m}$ depth; and the northern North Sea from 100 to $200 \mathrm{~m}$ depth. The assemblages of these zones are further structured by sediment composition. Before the North Sea Benthos Survey (NSBS) it was not possible to confirm or reject Glemarèc's concept of the zones in the North Sea.

Since in most earlier surveys sampling of bottom fauna was done with different gears, and surveys were spread over more than half a century, during which major changes occurred in the benthic fauna (Kröncke, 1990), the results of these surveys are not comparable. Participants of the Benthos Ecology Working Group of ICES therefore decided to map the benthic fauna of the whole North Sea during the same period of the year and with 


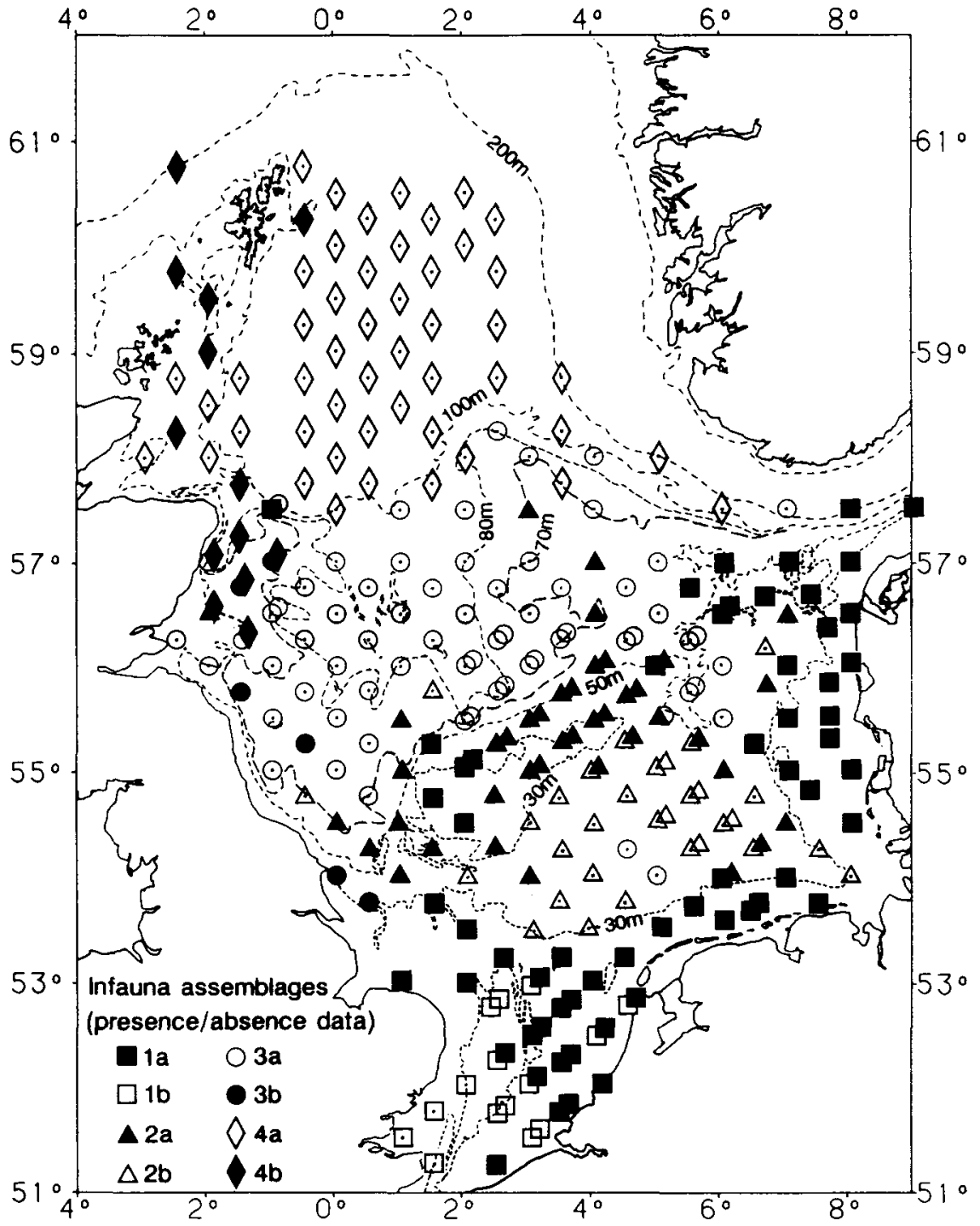

Figure 2. Classification of stations by TWINSPAN, using only species presence/absence data.

1st dichotomy

2nd dichotomy depth deposit

3rd dichotomy depth deposit
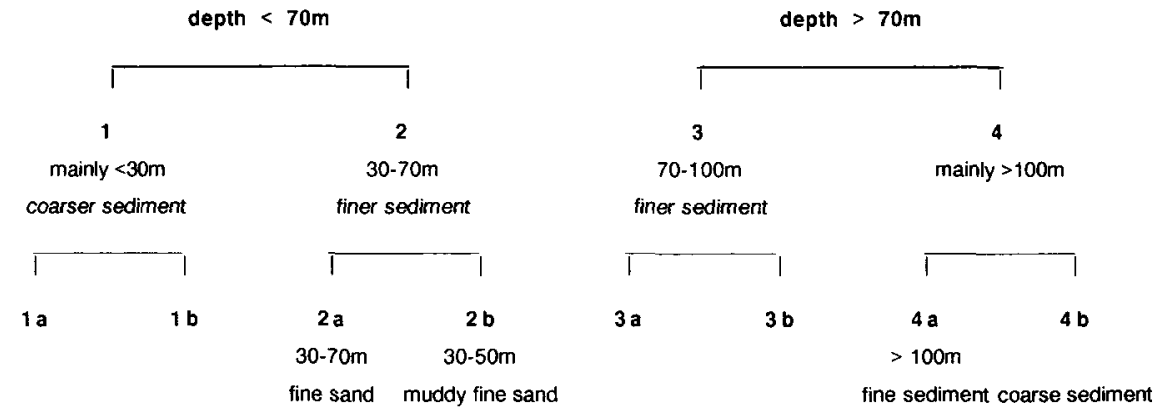

Figure 3. Scheme of TWINSPAN classification (species presence/absence data), showing the environmental parameters of the assemblages. 


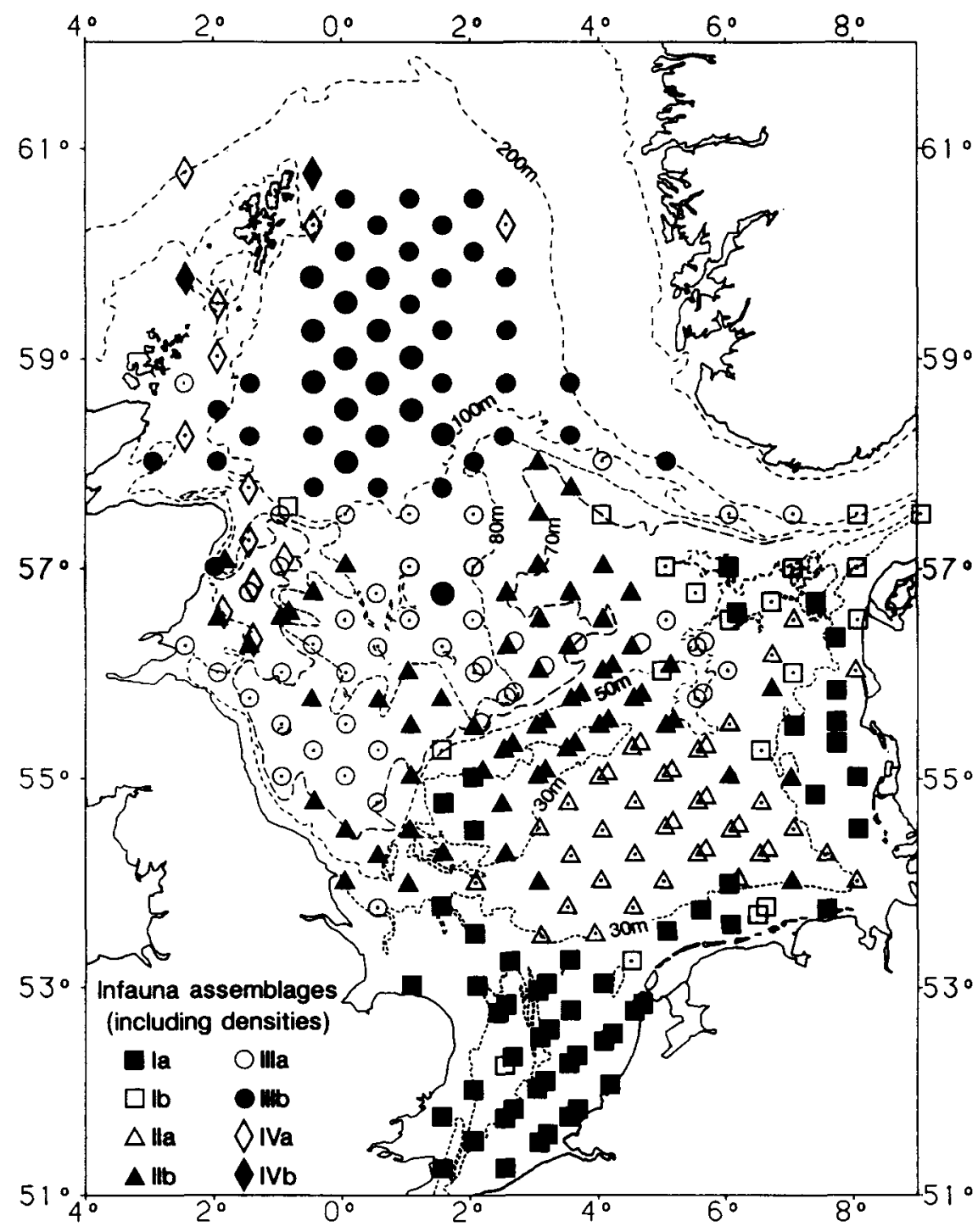

Figure 4. Classification of stations by TWINSPAN, incorporating species abundances.

standardized gear. This survey, the North Sea Benthos Survey (NSBS), was carried out during April 1986. The area north of $58^{\circ} \mathrm{N}$ could not be sampled during the NSBS but the benthic fauna of that area had been sampled directly between 1980 and 1985 by Eleftheriou and Basford (1989) with the same gear, and these data have been included in the analysis. The combined data of the NSBS and Eleftheriou and Basford (1989) provide information on the infauna of the whole North Sea and should act as a basis for assessing natural and anthropogenic changes in the benthos.

Besides the classification of the infauna into assemblages, the NSBS enables us to describe the distribution of single species within the whole North Sea area. So far, only the distribution of echinoderms (Ursin, 1960), polychaetes (Kirkegaard, 1969) and bivalves (Petersen, 1977) has been described for the central and southern North Sea. Almost nothing is known about the distribution of crustaceans, such as amphipods and cumaceans. The above mentioned authors found that the fauna of the North Sea was a mixture of arctic-boreal (North Atlantic-North Pacific elements) and lusitaneanboreal species (Tethys elements), the first being dominant north of the Dogger Bank, the latter being important south of it. This pattern of distribution was demonstrated for echinoderms and bivalves, the distribution of which was related to temperature and water bodies, but was less clear for polychaetes, which seemed to be related more to 


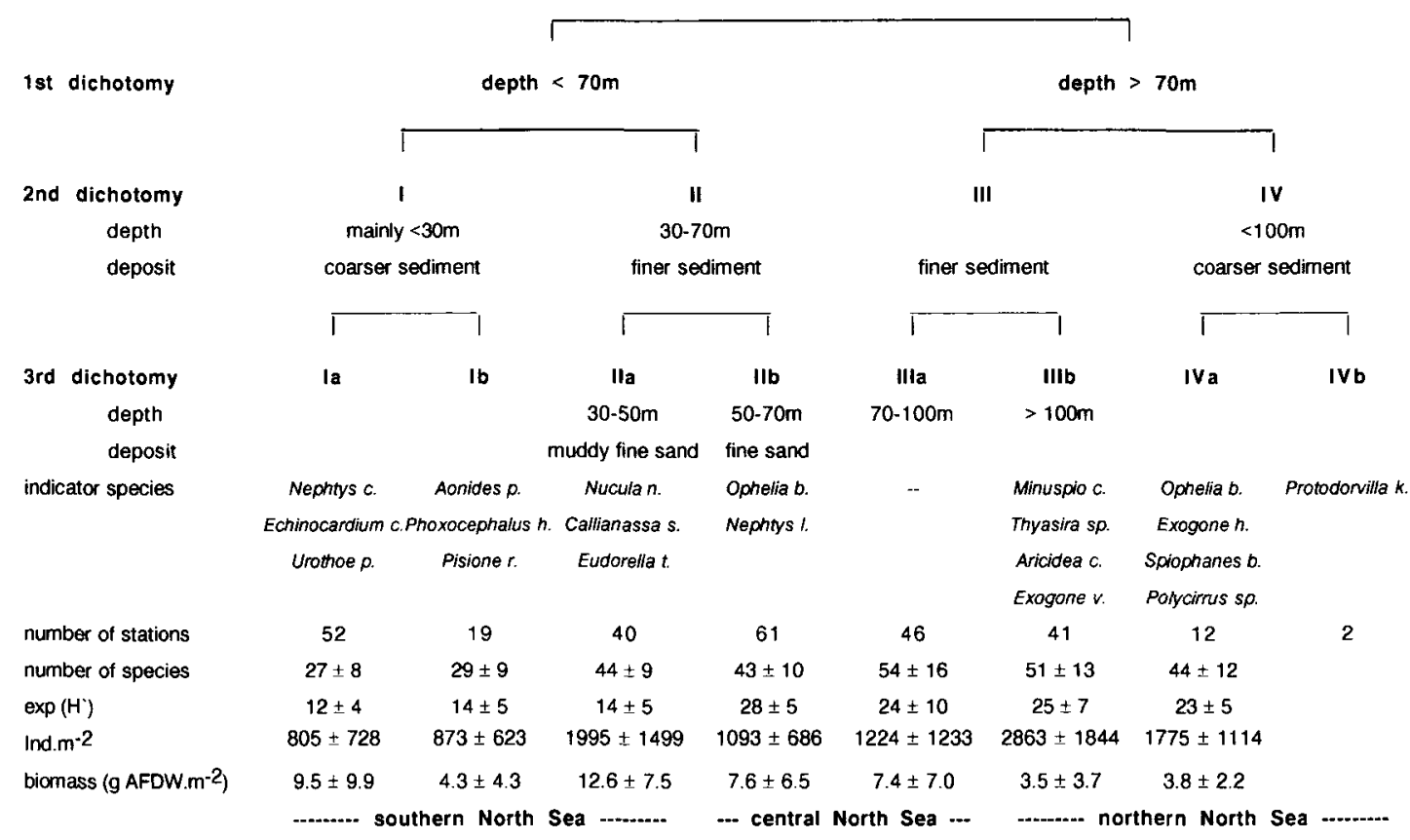

Figure 5. Scheme of TWINSPAN classification (species abundance data), showing the environmental and biotic parameters (mean \pm s.d.) of the assemblages and the indicator species.

the type of sediment. The present paper tries to combine the main pattern of species distributions with the distribution of infaunal assemblages in the North Sea.

\section{Materials and methods}

\section{Sampling}

Figure 1 shows the grid of 197 stations sampled during the NSBS in April 1986 and 63 stations sampled by Eleftheriou and Basford (1989) between 1980 and 1985, always in spring and early summer. The grid is of $30 \times 35 \mathrm{~nm}$ with four stations at the angles of the rectangle and one in the centre. At each station the infauna was sampled either by box sampler (usually three cores) and one van Veen grab or during bad weather conditions only by van Veen grab (usually three grabs). The numbers of samples per station and per participant are given in the fifth report of the ICES-Benthos Ecology Working Group (Anon., 1986). Samples were sieved over a 1-mm mesh (a $0.5-\mathrm{mm}$ mesh in the northern North Sea), preserved in $5 \%$ buffered formalin and sorted and identified by each participant.

\section{Taxonomic problems}

Although many taxonomical problems were solved during a special workshop on taxonomy of North Sea benthos held on Helgoland in 1988 (Heip and Niermann,
1988) where invited experts on certain taxonomic groups checked the identifications of species, the species list contained a lot of synonyms (e.g. Paramphinome jeffreysi $=P$. pulchella, Pectinaria auricoma $=$ Amphictene auricoma). Spelling and synonyms were checked using the Marine Conservation Society species directory, a coded checklist of the marine fauna and flora of the British Isles and its surrounding seas (Howson, 1987). The directory includes most of the species recorded during the NSBS. Species which do not really belong to the macrobenthos and hence, were badly sampled (e.g. fishes, larval stages, epibenthic species) were removed. During a final workshop on Texel in 1989 the identification of all species (including those of the northern North Sea) was checked among participants and uncertain identifications were amalgamated into wider groupings.

For the final workshop a list of "suspect" species was drawn up by calculating an index of particularity, expressing the degree to which species were found exclusively by one or a few laboratories. Depending on the number $\mathrm{S}_{\mathrm{obs}}$ of stations in which a species is found, one can calculate the number $L_{\text {exp }}$ of laboratories that should have found the species, if the latter were homogeneously distributed over the whole North Sea

$\mathrm{L}_{\text {exp }}=\sum_{\mathrm{i}=1}^{\mathrm{L}_{\mathrm{tot}}}\left\{1-\left(\frac{\mathrm{S}_{\mathrm{obs}}}{\mathrm{S}_{\mathrm{tot}}-\mathrm{S}_{\mathrm{i}}}\right) /\left(\frac{\mathrm{S}_{\mathrm{tot}}}{\mathrm{S}_{\mathrm{obs}}}\right)\right\}$,

where $S_{\text {tot }}=$ total number of stations, $S_{i}=$ number of stations sampled by laboratory $i, L_{t o t}=$ total number of 


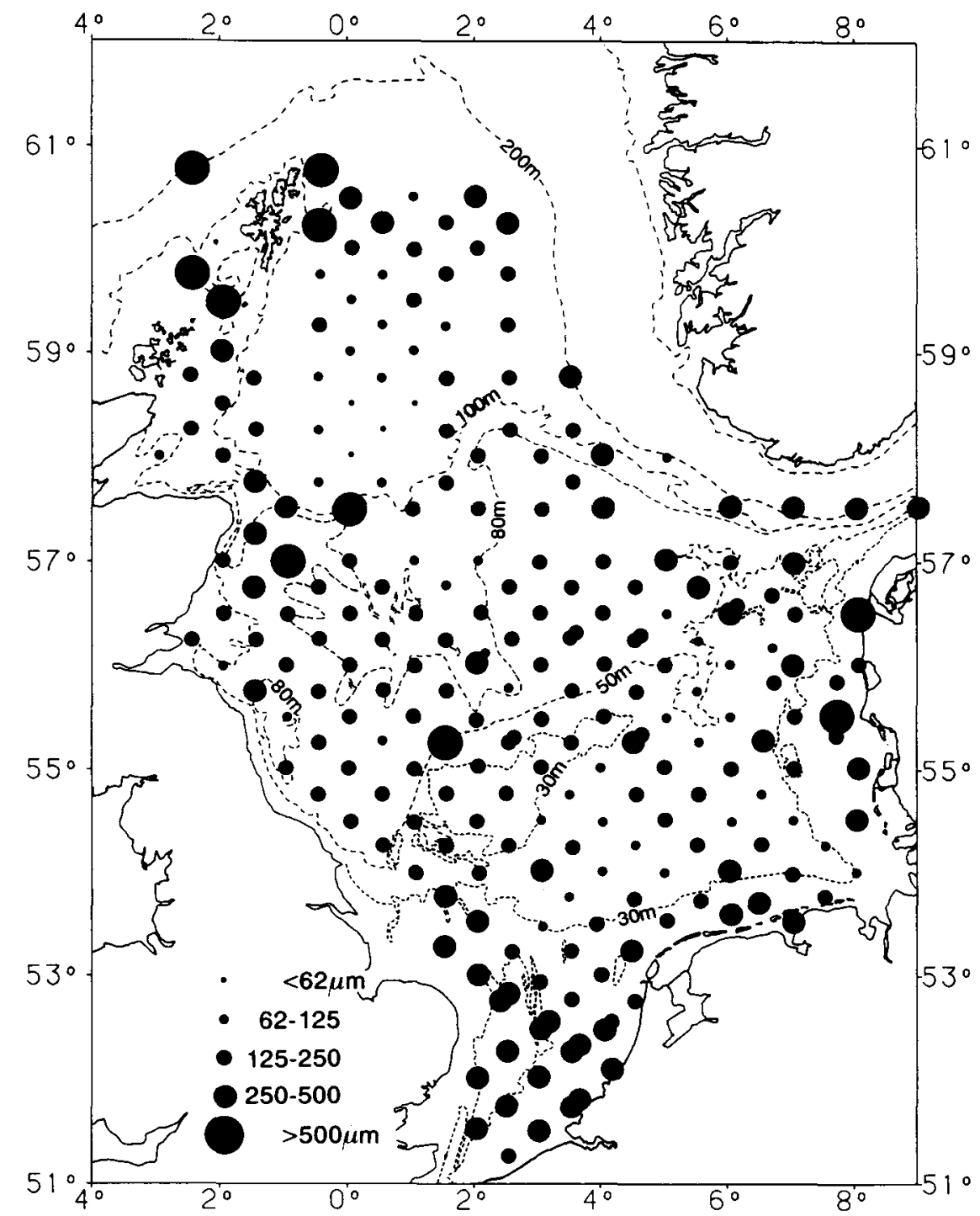

Figure 6. Median grain size of the sediment at each station (analysed by Irion, Wilhelmshaven and Basford, Aberdeen) and depth distribution in the North Sea.

laboratories. The index of particularity describes the degree of digression from this hypothesis of homogeneity, by calculating

$$
\text { PISP }=\mathrm{L}_{\text {exp }}-\mathrm{L}_{\mathrm{obs}} \text {, }
$$

where $\mathrm{L}_{\text {obs }}=$ number of laboratories that have found the species. The assumption of homogeneous distribution over the North Sea is in itself nonsensical but the index provided a basis for a thorough discussion of taxonomy used between the participants. An auxiliary basis for this discussion was a computerized atlas showing the spatial distribution of all species, genera, families and phyla.

The list of "suspect" species proved very useful. Although many species were recognized by everybody, and were restricted to a few laboratories due to change or due to their geographical distribution, several tens of species in the list turned out to be identified to different levels by different laboratories, or simply given different names following different taxonomical handbooks. This source of error was remedied as much as possible in the discussions.

Species identified to different levels had to be lumped together. Three examples are given. First, different laboratories used different identification keys and not every key differentiated all species. Pholoe pallida of Chambers (1985), for instance, is not mentioned in other keys (e.g. Hartmann-Schröder, 1971; Fauvel, 1923) and there is confusion between this species, $P$. inornata and 

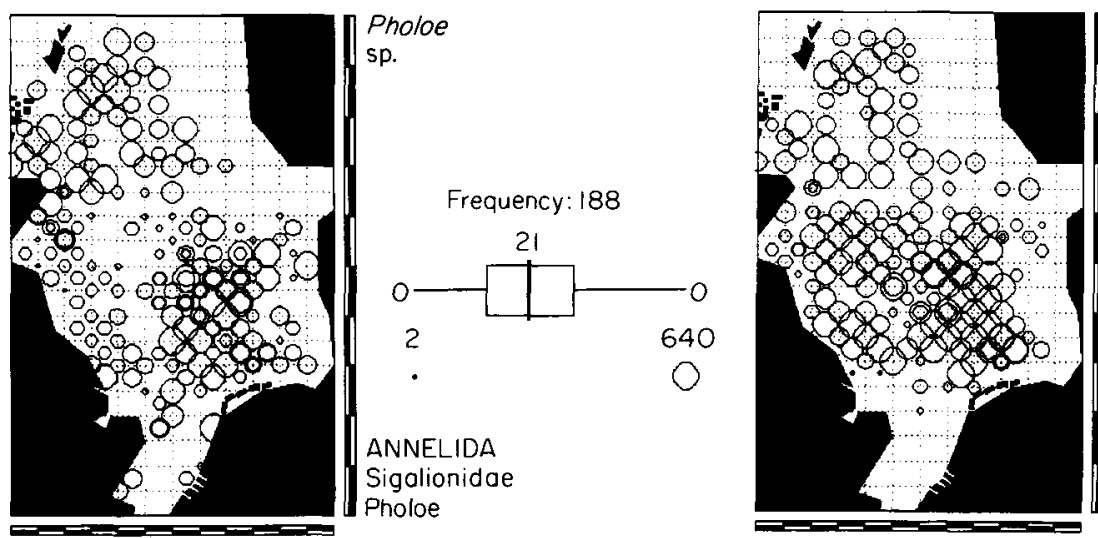

Amphiuro

filiformis
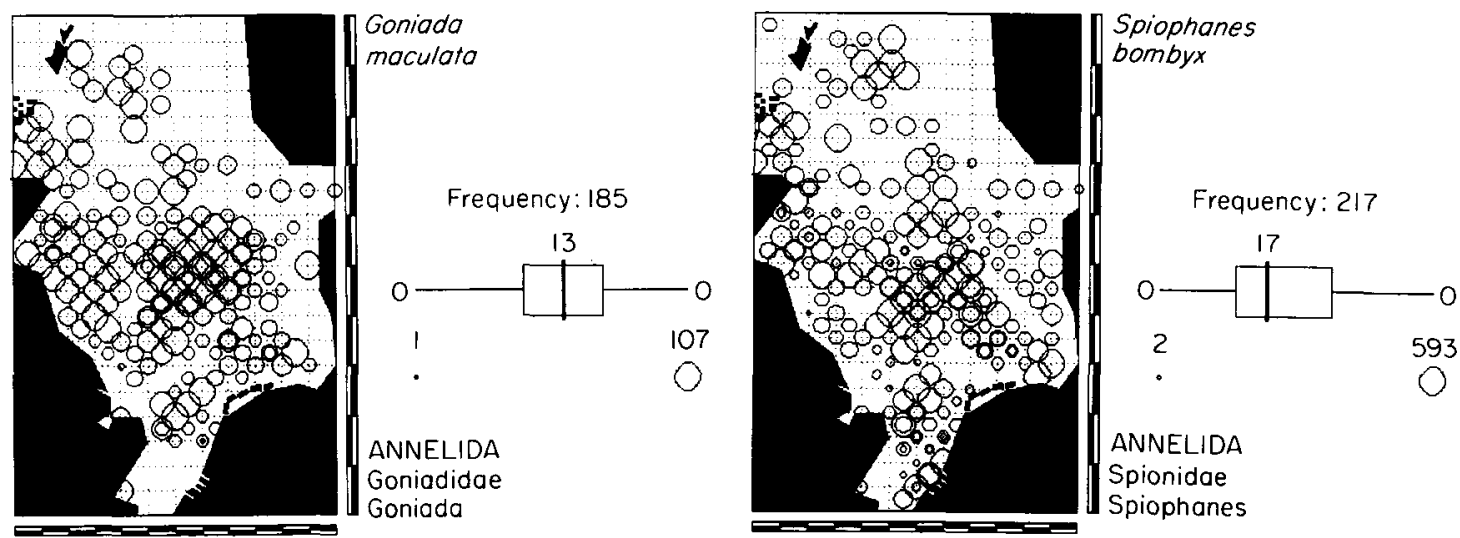

Figure 7. Distribution and density of species with a wide occurrence in the North Sea. (See Methods for further explanation.)

P. minuta. Consequently, they were all lumped at the genus level. Among others, species of the genera Ensis, Lunatia, Thyasira, Magelona, Myriochele and Tharyx were also lumped at the genus level. Second, some laboratories identified taxa as e.g. the sipunculids, the holothurioids, the anthozoans and the nemerteans to the species level, others did not. Third, even well-established laboratories have different opinions on the taxonomy of some species. It was felt that some taxa (e.g. the capitellids) need a review before accurate identification can be made.

The revised species list finally contained 954 different taxa. Before, there had been 1270 taxa. The TWINSPAN analysis has been carried out on the basis of 709 taxa.

\section{TWINSPAN analysis}

Stations were grouped according to their similarity in species composition using TWINSPAN analysis (Hill, 1979). This Fortran program divides the ordinated stations into two groups (first dichotomy) and proceeds by dividing each group into two further groups (second dichotomy) and so on. This analysis was run twice, first, solely with binary (presence or absence of a species) data and second, taking the actual abundances of the species into account. At each division indicator species are given. In TWINSPAN, indicator species are those species which occur at most stations of the one group but at nearly no stations of the other group, and species which occur at higher densities in one group.

\section{Diversity}

As a measure of faunal diversity $\exp \left(\mathrm{H}^{\prime}\right)$ was used where $\mathrm{H}^{\prime}$ is the Shannon-Wiener diversity calculated with natural logarithms (Hill, 1973).

\section{Biomass}

Depending on the institute, the biomass was measured either directly as ash-freedry weight or calculated from wet weight using appropriate conversion factors (Salzwedel et al., 1985; Rumohr et al., 1987).

\section{Maps of species distribution}

On the maps of species distribution (see Figs 7 to 16 ) occurrences of species are indicated by circles. The radius of the circle is proportional to the log-transformed abundance of the species. The box and whisker plot 

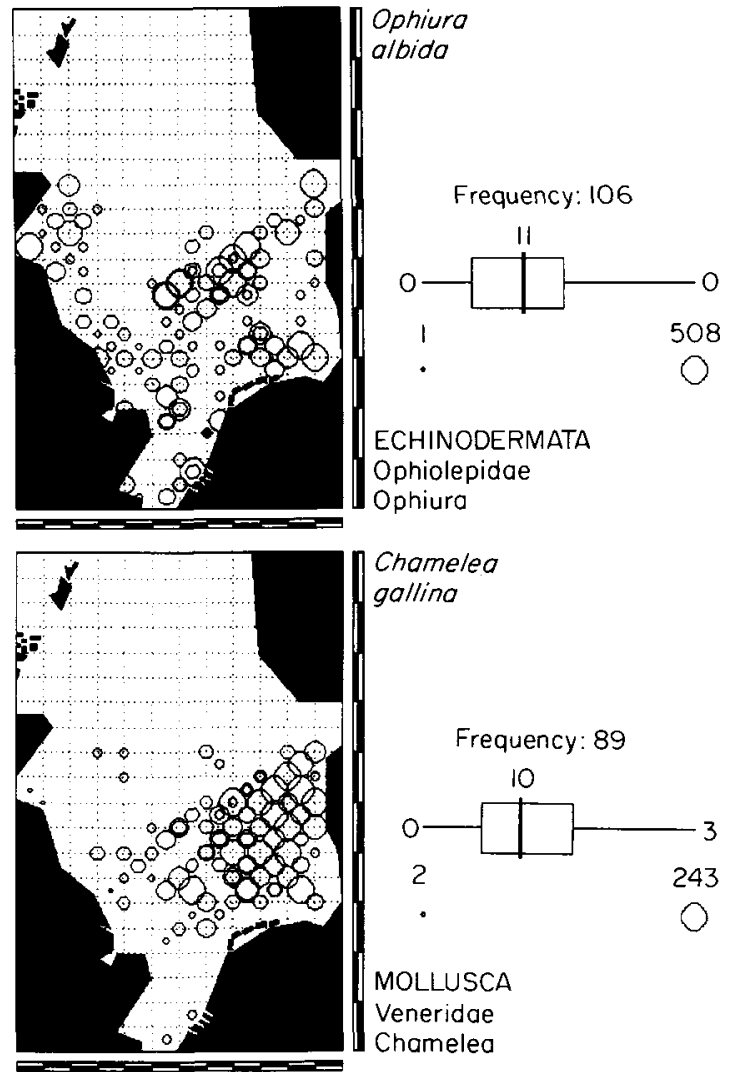

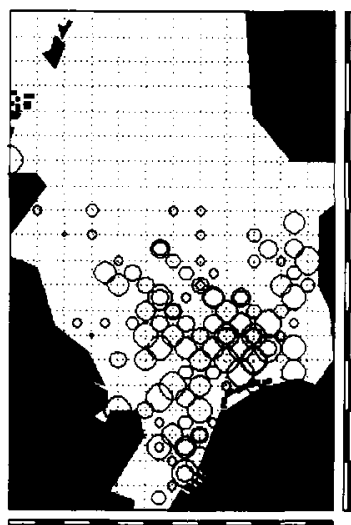

Echinocardium cordatum

cordatum
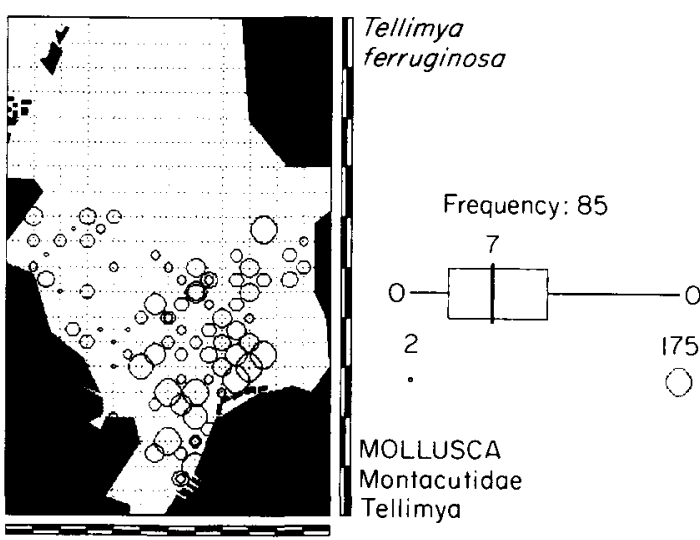

Figure 8. Distribution and density of species with a southern occurrence in the North Sea.

expresses the frequency distribution of the non-zero observations on a logarithmic scale. The numbers of outliers are given by the numbers to the right and left of the box and whisker plots.

\section{Results}

\section{Assemblages}

Differences in the benthic fauna of the North Sea were elaborated by running the TWINSPAN analysis first with binary (presence or absence of species) data and second, taking the actual abundances of species into account. Figure 2 shows the stations of similar species composition based on presence/absence data and Figure 4 shows the similarity in species composition when densities are taken into account. The areas inhabited by certain assemblages remain more or less the same in both cases. The type of sediment at each station is shown in Figure 6.

\section{Assemblages based on presence or absence of species}

Figure 3 gives the scheme of TWINSPAN classification for the eight different assemblages which are shown in Figure 2. The classification was based on presence/ absence data. The infauna assemblages of the North Sea are determined by the depth and by the sediment type.

At the first dichotomy most stations north of the Dogger Bank (indicator species: Spiophanes kröyeri, Myriochele sp., Minuspio cirrifera, Antalis entalis) were separated from the stations south of the 70-m depth contour (indicator species: Magellona sp., Echinocardium cordatum). The benthic fauna of the deeper northern half of the North Sea is different from the fauna of the shallower southern half.

At the second dichotomy the stations south of the $70-\mathrm{m}$ depth contour were divided along the 30-m depth contour into those with coarser sediment mainly shallower than $30 \mathrm{~m}$ (group 1, no indicators) and those with a sediment of fine sand and with a depth generally greater than $30 \mathrm{~m}$ (group 2, indicators: Amphiura filiformis, Phoronis sp., Pholoe sp., Mysella bidentata, Nephtys hombergi, Cylichna cylindracea, Harpinia antennaria). The stations north of the 70-m depth contour were divided mainly by the 100-m depth contour into those in the central North Sea (group 3, indicators: Mysella bidentata, Scoloplos armiger, Chaetoderma nitidulum) and those in the northern North Sea (group 4, indicators: Exogone verugera).

At the third dichotomy stations near the English Channel (group 1b, indicators: Glycera lapidum, 

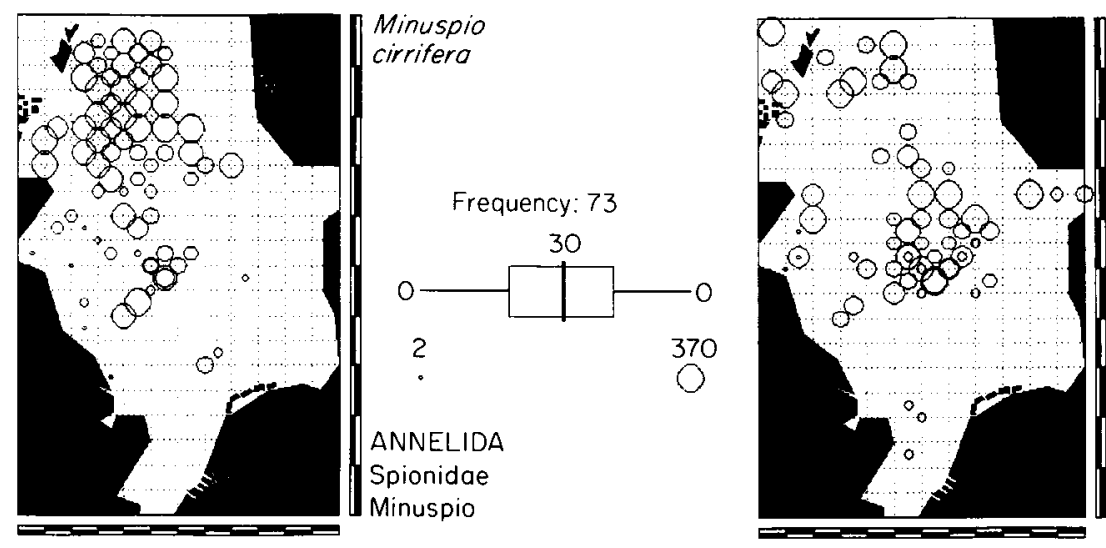

Ophiura

affinis
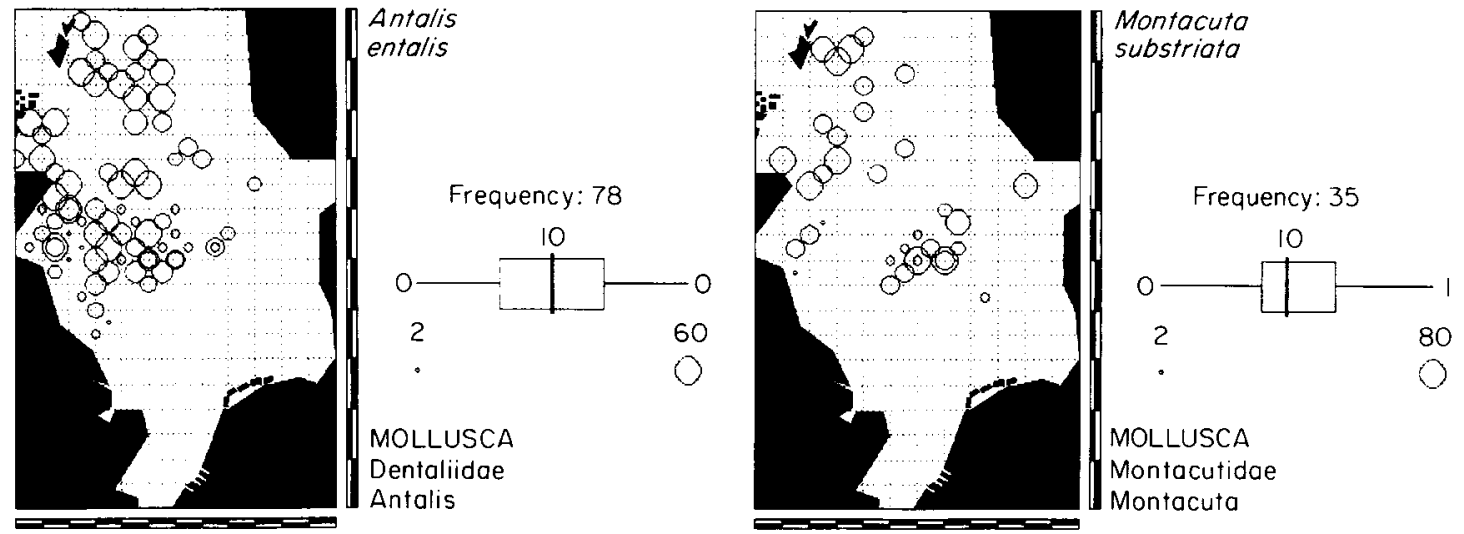

Figure 9. Distribution and density of species with a northern occurrence in the North Sea.

Polycirrus medusa) were separated from the other stations on coarse sediment in the southern North Sea (group la, indicators: Fabulina fabula, Lunatia poliana). The stations on fine sand were further divided into stations on muddy fine sand south of the Dogger Bank (group 2b, indicators: Eudorella truncatula, Callianassa subterranea, Ampelisca tenuicornis, Nucula nitidosa, Harpinia antennaria, Chaetopterus variopedatus) and those on clean fine sand in the central North Sea mainly north of the Dogger Bank and on the Dogger Bank (group 2a, no indicators). In the central North Sea some stations along the English coast (group 3b, indicators: Glycera lapidum, Leptochiton asellus) have a different fauna than the other stations (group 3a, no indicators). Within the northern North Sea, stations along the Scottish coast including the Orkneys and Shetlands, being mainly shallower than $100 \mathrm{~m}$ depth and with coarse sediment (group $4 \mathrm{~b}$, indicators: Spaerosyllis bulbosa), were different from those deeper than $100 \mathrm{~m}$ on muddy fine sand (group 4a, indicators: Thyasira sp.).

\section{Assemblages based on abundance of species}

Figure 5 gives the scheme of TWINSPAN classification, based on species abundances, for the assemblages which are shown in Figure 4. This classification gave about the same results as the analysis with presence/absence of species. In comparison to the analysis described before, the assemblages of the northern and central North Sea seem to be more similar. The borderline between southern and northern assemblages is shifted slightly towards the north.

At the first dichotomy stations were separated along the 70-m depth contour into stations to the north (indicator species: Spiophaneskröyeri, Minuspiocirrifera, Myriochele sp.) and stations to the south of it (indicator species: Echinocardium cordatum, Magelona sp., Bathyporeia elegans).

At the second dichotomy among the stations south of the 70-m depth contour, those on coarser sediment (group I, no indicators) were separated from those on fine sand (group II, indicators: Amphiura filiformis, Pholoe sp., Phoronis sp., Mysella bidentata, Harpinia antennaria, Cylichna cylindracea, Nephtys hombergi). Among the northern stations those along the Scottish coast on coarse sediment (group IV, indicators: Sphaerosyllis bulbosa, Hesionura elongata) were separated from the other stations in the central and northern North Sea (group III, indicators: Levinsenia gracilis, Thyasira sp.).

At the third dichotomy stations north-west of Denmark (group Ib, indicators: Aonides paucibranchiata, Phoxo- 

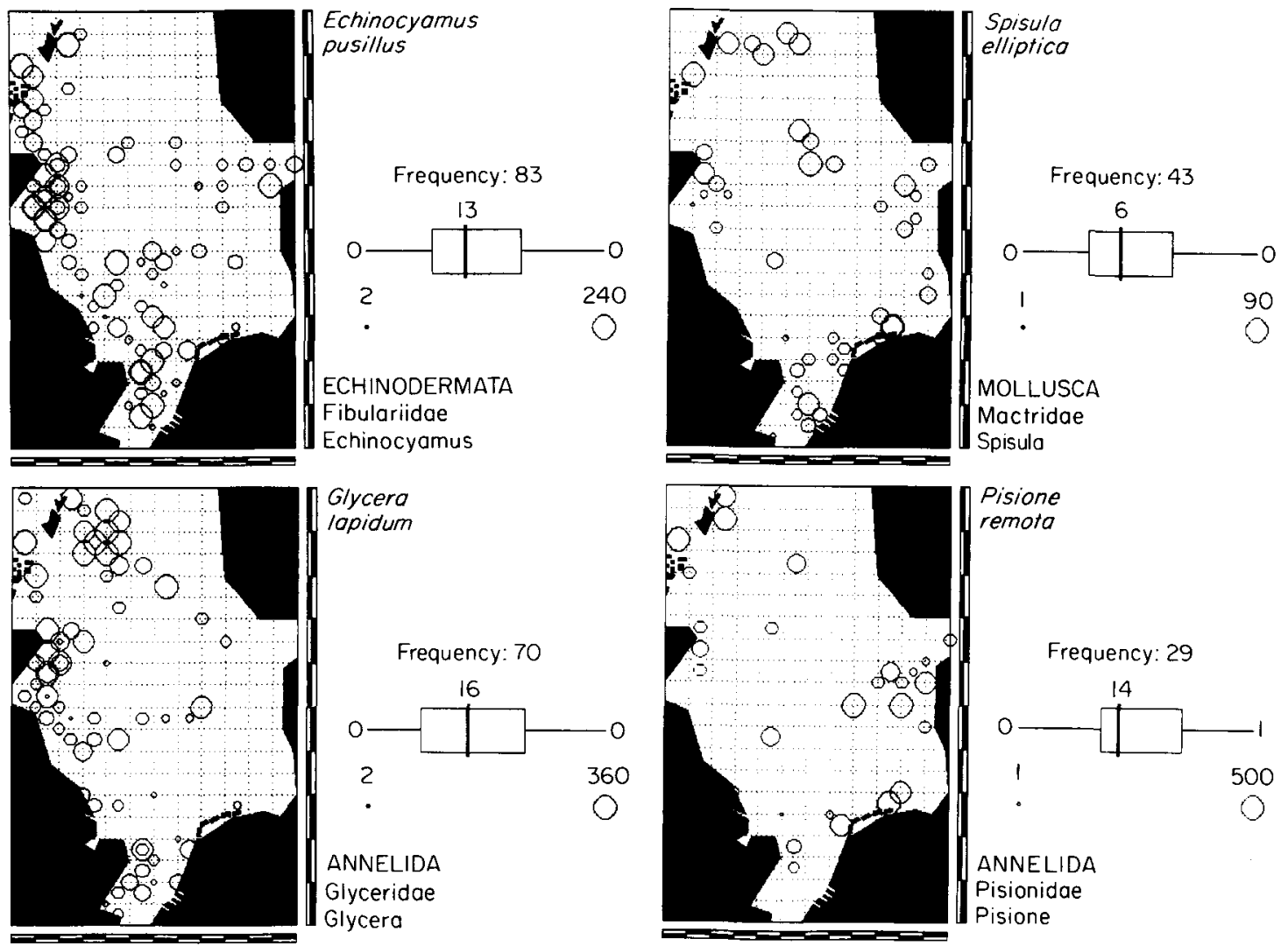

Figure 10. Distribution and density of species with a wide occurrence on coarse sediments in the North Sea.

cephalus holbolli, Pisione remota) were separated from the other stations on coarser sediment (group Ia, indicators: Nephtys cirrosa, Echinocardium cordatum, Urothoe poseidonis). The stations on fine sand were divided into those on muddy fine sand south of the Dogger Bank (group IIa, indicators: Nucula nitidosa, Callianassa subterranea, Eudorella truncatula) and those on fine sand in the central North Sea at 50-70-m depth (group IIb, indicators: Ophelia borealis, Nephtys longosetosa). Stations deeper than $70 \mathrm{~m}$ were divided along the $100-\mathrm{m}$ depth contour into those of the northern North Sea (group IIIb, indicators: Minuspio cirrifera, Thyasira sp., Aricidea catherinae, Exogone verugera) and those of the central North Sea at about 70-100-m depth (group IIIa, no indicators).

\section{Species number, diversity, density, biomass}

The difference in biotic parameters among the assemblages is shown in Figure 5 for the species number, diversity, density and biomass.

Species number and diversity gradually increase from the assemblages shallower than $30 \mathrm{~m}$ (group Ia, Ib) to the assemblages in the 30-70-m depth (group IIa, IIb) and are highest in the assemblages in areas deeper than $70 \mathrm{~m}$ (group IIIa, IIIb). Towards the Scottish coast (group IV) species number and diversity decrease again.

The variation in densities is too high to show clear differences between assemblages. Densities seem to be lower in the assemblages on shallow coarse sediment (group Ia, Ib). They seem to be highest in group IIIb but at stations in this group a finer mesh of $0.5 \mathrm{~mm}$ instead of $1.0 \mathrm{~mm}$ was used. Also at the stations of group IV the $0.5-\mathrm{mm}$ mesh was used, and therefore densities are higher than they would have been by using a 1-mm mesh and are not directly comparable to the densities in group I and II.

The variation in biomass is also very high. The mean biomass per assemblage is lowest in the northern North Sea (groups IIIb and IV). The biomass increases towards the shallower southern North Sea and reaches highest values south of the Dogger Bank (group Ia, IIa).

\section{Species distribution}

Since it is impossible to show the distribution of all species in the North Sea, only a few examples will be given here to show the main patterns. These species were chosen, because they were shown to be typical of individual 

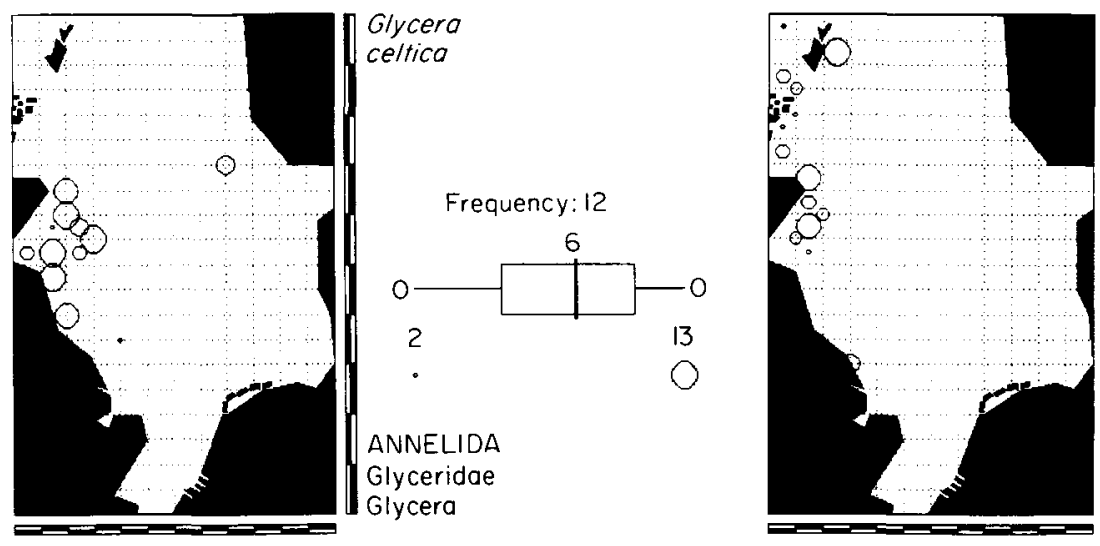

Sphaerosyllis bulbosa

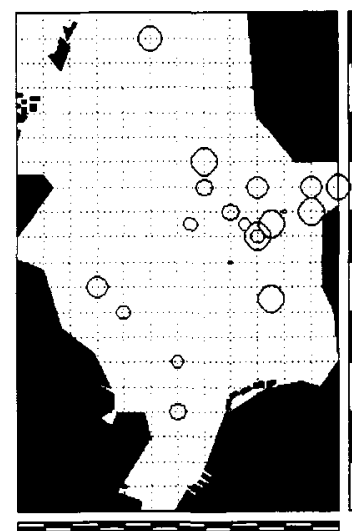

Phoxocephalus

holboll

Figure 11. Distribution and density of species with a restricted occurrence on coarse sediments in the North Sea.

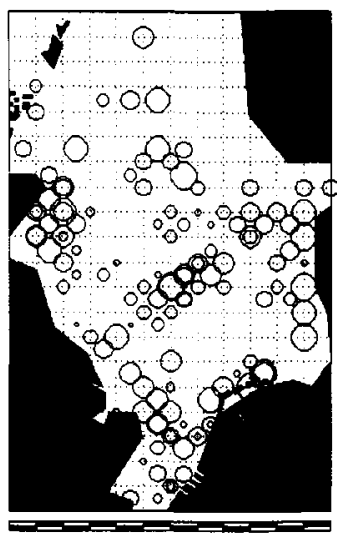

Ophelia

borealis

ARTHROPODA

Phoxocephalidae

Phoxocephalus
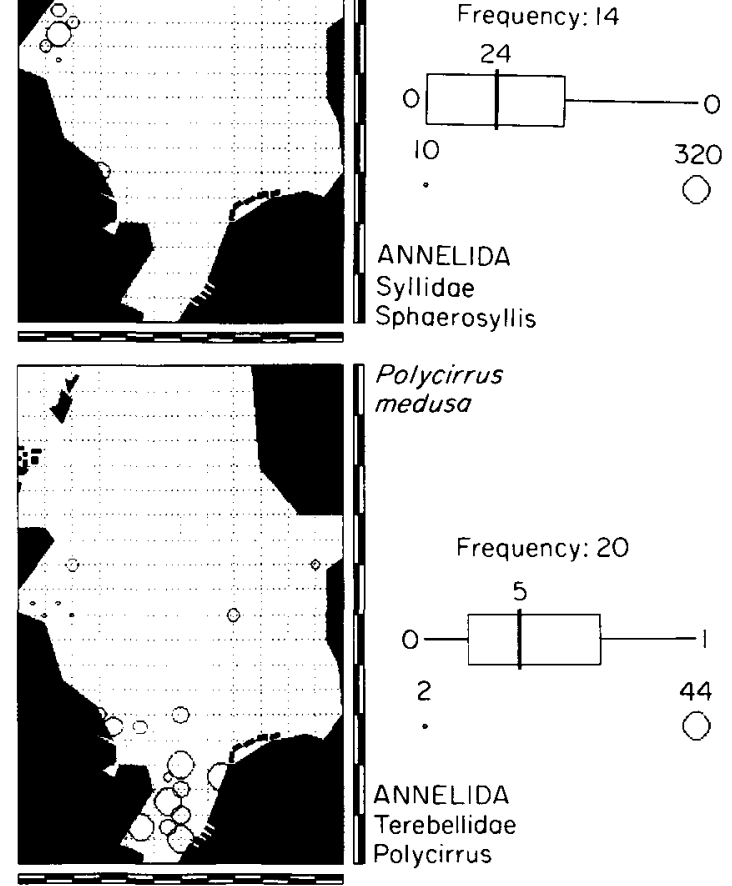

ANNELIDA

Syllidae

Sphaerosyllis
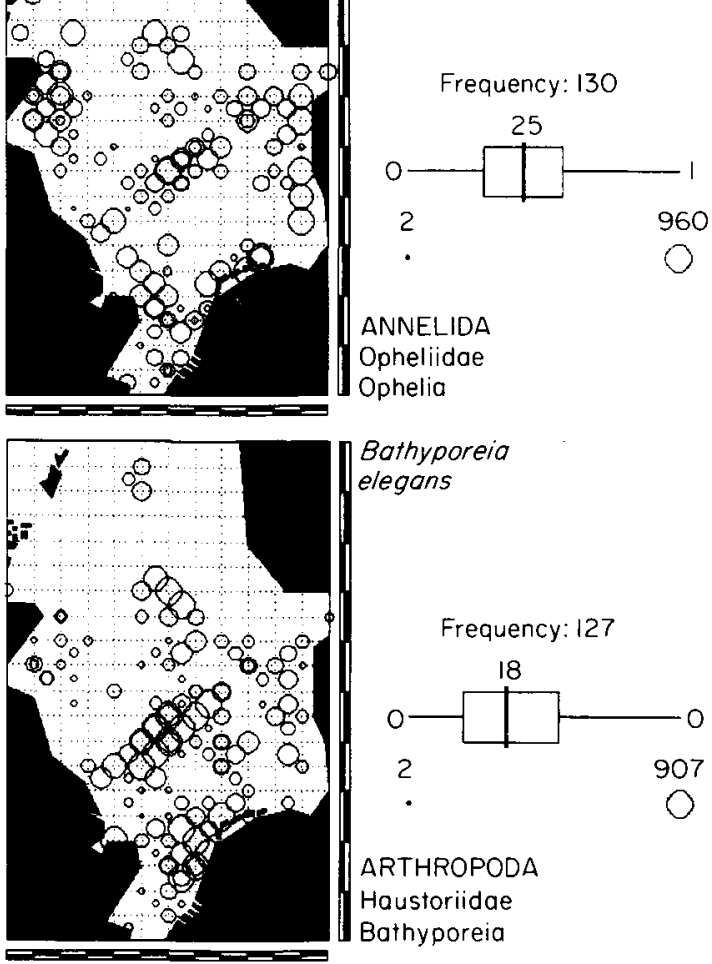

ANNELIDA

Opheliidae

Ophelia

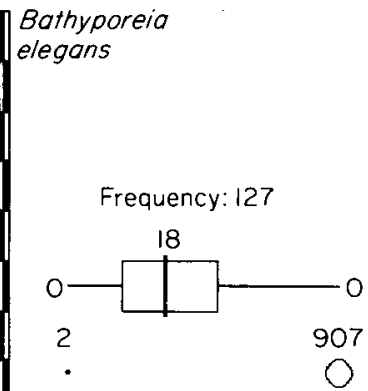

ARTHROPODA

Houstoriidae

Bathyporeia

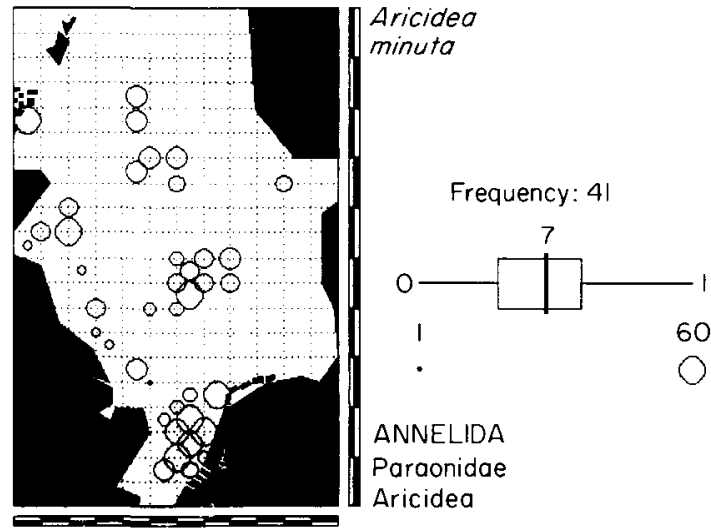

Figure 12. Distribution and density of species with a wide occurrence on fine sand in the North Sea. 


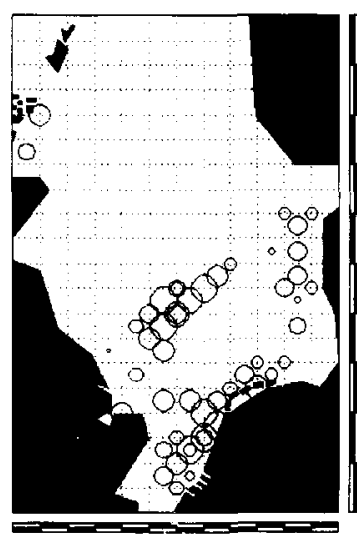

Bathyporeia guilliamsoniana

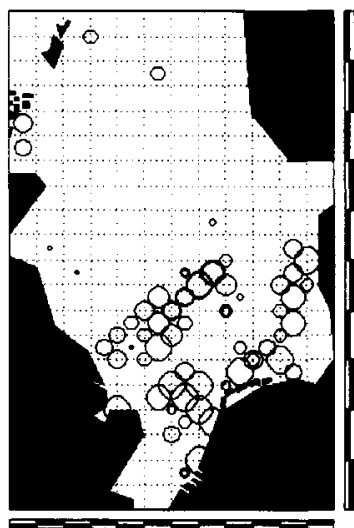

Fabulina

Frequency: 54

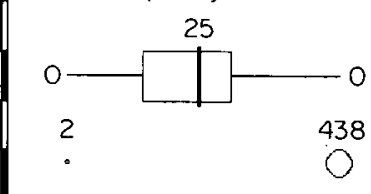

ARTHROPODA

Haustoriidae

Bathyporeia

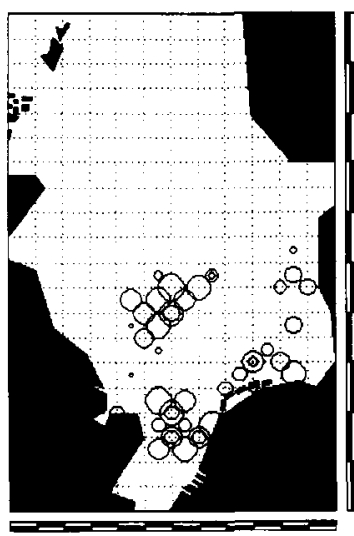

Urothoe

poseidonis

requency: 45

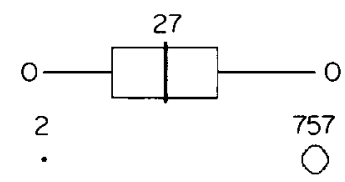

ARTHROPODA

Haustoriidae

Urothoe

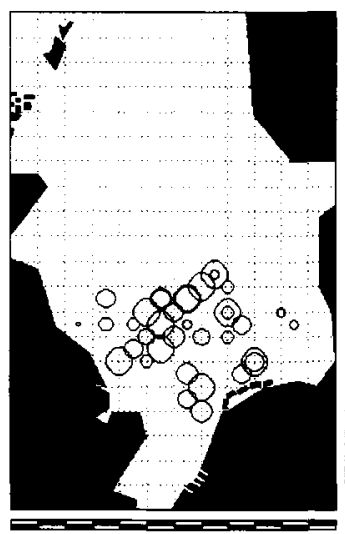

Sigalion

mathildae

Frequency: 68

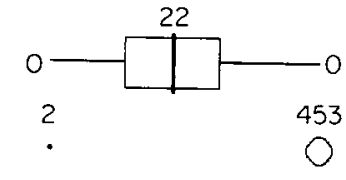

MOLLUSCA

Tellinidae

Fabulina

Figure 13. Distribution and density of species with a restricted occurrence on fine sand in the southern North Sea.

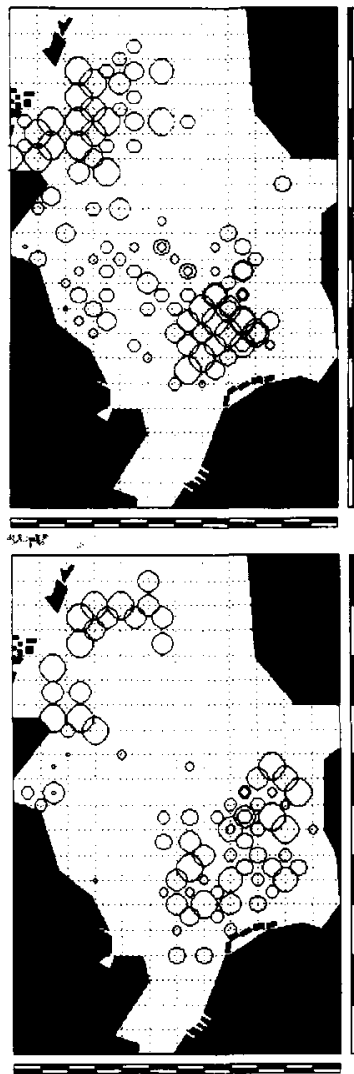

Herpinia

antennario

Frequency: 105

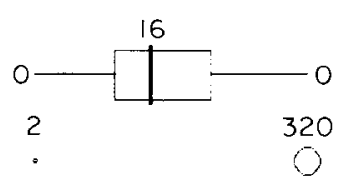

ARTHROPODA

Phoxocephalidae

Harpinia

Glycinde

nordmanni

Frequency: 79
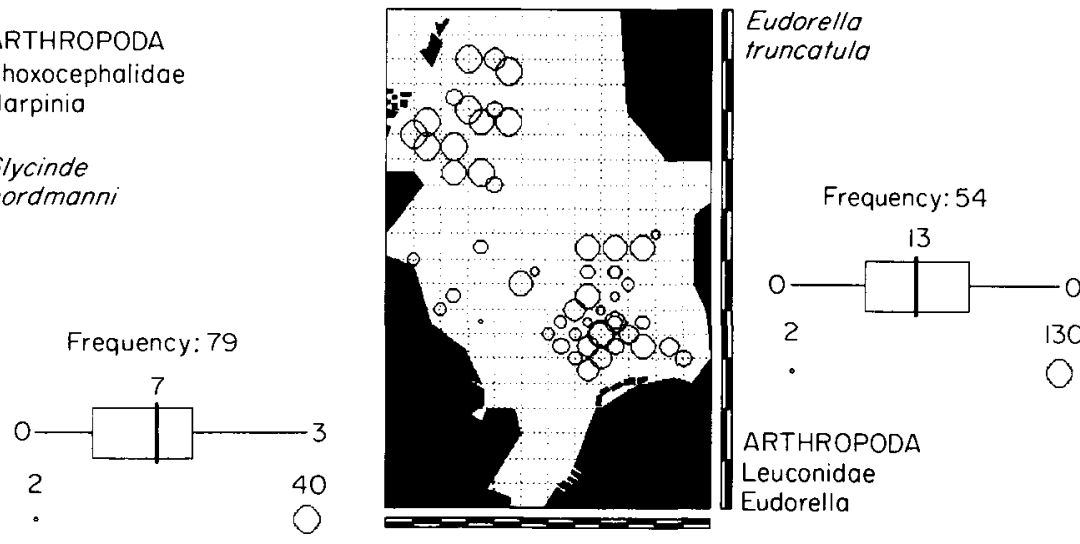

ANNELIDA

Goniadidae

Figure 14. Distribution and density of species with a wide occurrence on muddy fine sand in the North Sea. 

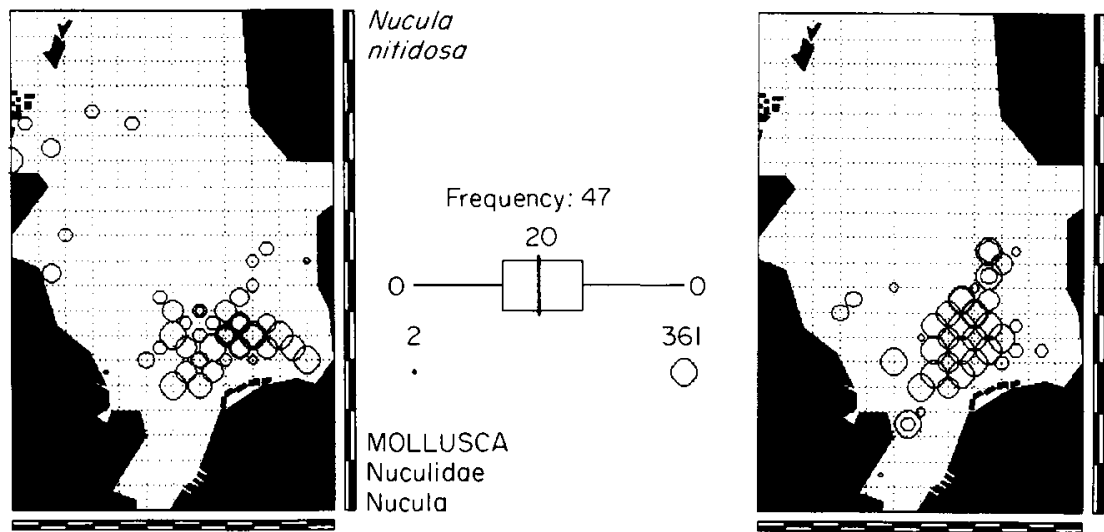

Callianassa

subterranea
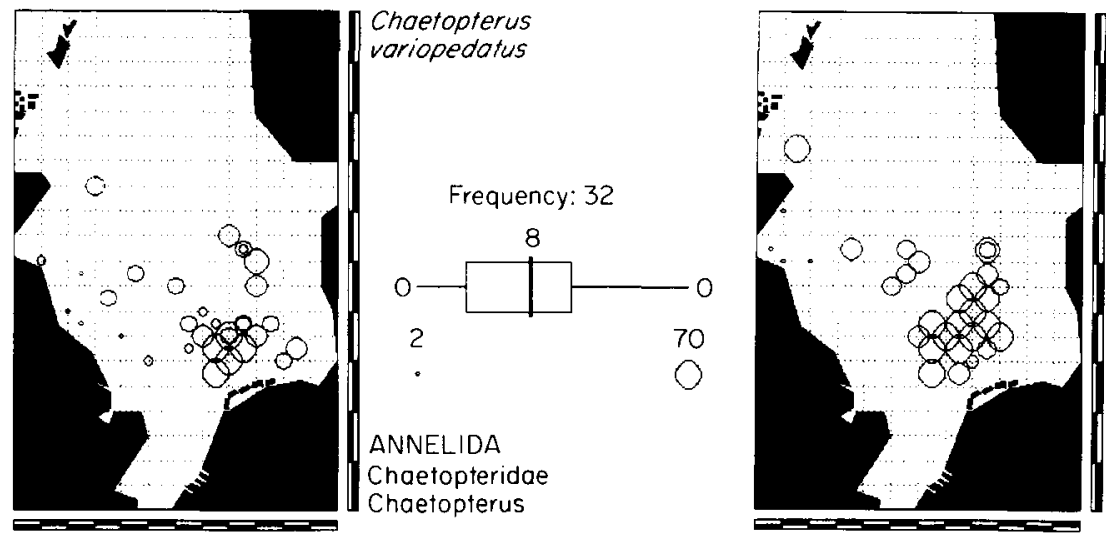

klatti

Frequency: 43

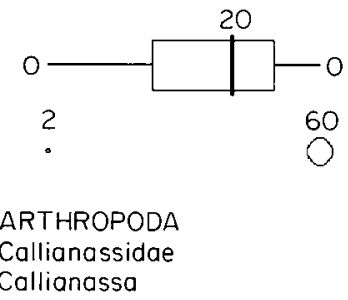

Figure 15. Distribution and density of species with a restricted occurrence on muddy fine sand in the southern North Sea.

assemblages identified by the TWINSPAN analysis. Typical for an assemblage means that the species occur at most stations of this assemblage but at nearly no stations of the adjacent assemblages. Not all indicator species mentioned above are shown because they are only indicators for the division and must not be typical for an assemblage.

The distribution of individual species varies, some species being more cosmopolitan than others. Species with more restricted distribution can be used to describe the assemblages that inhabit specific areas. In the North Sea some species, eg. Spiophanes bombyx, Pholoe sp., Goniada maculata and Amphiura filiformis (Fig. 7), occur widely at nearly all depths and in a wide variety of sediments. Most species are either distributed south of a line parallel to the northern edge of the Dogger Bank (50-m depth contour) or north of it.

Species with a southern distribution may occur also in the central North Sea but never north of the $100-\mathrm{m}$ contour at $57-58^{\circ} \mathrm{N}$ : examples are Ophiura albida, Echinocardium cordatum, Chamelea gallina and Tellimya ferruginosa (Fig. 8). Some of these species mainly occur in the central North Sea, like Chaetoderma nitidulum and Ampelisca tenuicornis (not shown here).
Species with a northern distribution were usually never found south of the 50-m depth contour, e.g. Ophiura affinis, Montacuta substriata, Antalis entalis and Minuspio cirrifera (Fig. 9). Species with northern and southern distributions, respectively, caused the division into northern and southern assemblages along the 70-m depth contour.

The distribution of species also seems to be determined by the sediment. On coarse sediments Echinocyamus pusillus, Pisione remota, Glycera lapidum and Spisula elliptica occur all over the North Sea (Fig. 10), while Sphaerosyllis bulbosa and Glycera celtica are restricted to coarse sediments along the Scottish coast, and Polycirrus medusa and Phoxocephalus holbolli are restricted to coarse sediments in the south and east of the North Sea (Fig. 11). On fine sand Aricidea minuta, Bathyporeia elegans and Ophelia borealis occur all over the North Sea (Fig. 12), but Bathyporeia guilliamsoniana, Fabulina fabula, Urothoe poseidonis and Sigalion mathildae were only found in the southern North Sea on fine sand at depths less than $30 \mathrm{~m}$ (Fig. 13). Sediments of muddy fine sand occur mainly in the southern North Sea at 30-50 m depth and in the west of the northern North Sea (Fig. 6). Species with a wide distribution on this sediment are Eudorella truncatula, Glycinde nordmanni and Harpinia antennaria (Fig. 14). 

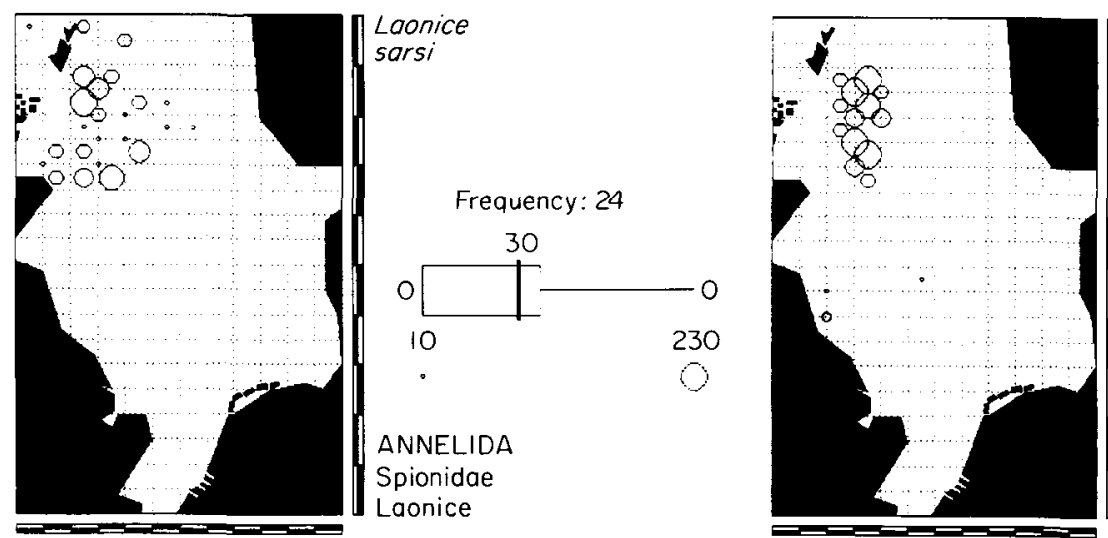

Leucon

nasica
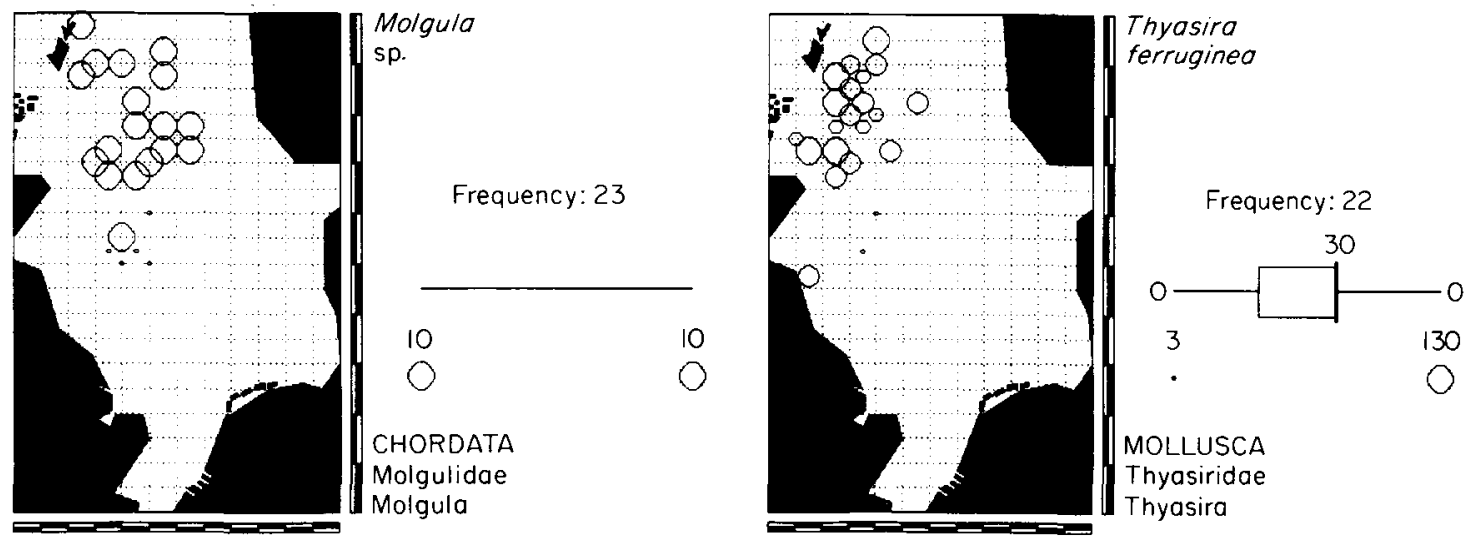

Figure 16. Distribution and density of species with a restricted occurrence on muddy fine sand in the northern North Sea.

Callianassa subterranea, Nucula nitidosa, Chaetopterus variopedatus and Synelmis klatti are restricted to the southern North Sea (Fig. 15) and Leucon sarsi, Thyasira ferruginea, Laonice sarsi and Molgula sp. are restricted to the northern North Sea (Fig. 16).

\section{Discussion}

Only the main patterns of species distributions have been described in this paper. They show that the bottom fauna of the North Sea is composed of northern elements that do not extend further south than the north of the Dogger Bank, and southern elements going not further north than the 100-m contour. Northern and southern species therefore mix in the central North Sea and northern and southern assemblages overlap along the $70 \mathrm{~m}$ contour. The occurrence of cold water species north of the Dogger Bank and of warm water species in the southern North Sea was already recognized by Ursin (1960), Kirkegaard (1969) and Petersen (1977). None of these authors, however, showed that the southern species occurred as far north as the 70-100-m depth contour.

The methodological difference in the mesh size of the sieve $(0.5 \mathrm{~mm}$ at stations in the northern North Sea, $1 \mathrm{~mm}$ at all other stations) might have had an effect on the
TWINSPAN analysis which included species abundances (Fig. 4). To avoid this possible error, the classification was carried out first only with presence/absence data where densities were excluded from the analysis (Fig. 2). In both classifications the assemblages in the northern half of the North Sea were divided by the $100-\mathrm{m}$ depth contour. The distribution of individual species also confirmed that three different assemblages exist in that area: one in Scottish coastal areas, one in offshore areas deeper than $100 \mathrm{~m}$ and one in the deeper part of the central North Sea.

Jones (1950) reviewed the literature on marine bottom communities. He found that most authors were in agreement that the communities, in the sense used by Petersen, were realities. All authors were agreed that there is a correlation between the distribution of the animal communities and certain physical factors. The biological factors, like relationships with other organisms, the presence of suitable food animals for predators, parasitism, commensalism, etc. seemed to be of secondary importance. Biological factors are of importance regarding the persistence of an assemblage. The persistence in the species composition of an assemblage is a function of the biological factors. Josefson (1981) showed that in a benthic community at $300 \mathrm{~m}$ depth in the Skagerrak the persistence was lower than at a shallower $100-\mathrm{m}$ community. At $300 \mathrm{~m}$ depth about $30 \%$ of numbers and 
biomass were replaced over a 5-year period. Parts of these changes could be interpreted in terms of amensalism and commensalism between trophic or functional groups of species. The persistence of a 80-m community off the coast of Northumberland has been shown to be lower than that of a $55-\mathrm{m}$ community due to sequential changes in the dominant species which were regarded as evidence of biological interaction (Buchanan and Moore, 1986). The significant environmental factors determining assemblages were shown by Jones (1950) to be temperature, salinity and the nature of the bottom deposit. Within the Atlantic boreal region Jones divided the benthos by the temperature range and salinity range into shallow water communities, offshore communities and deep communities. The latter have their upper limits of distribution at $70 \mathrm{~m}$ depth. These communities were further structured by the sediment.

In his model of three infaunal étages in the North Sea, Glemarec (1973) demonstrated the 50- and 100-m contours as being important structuring borders for the assemblages in the North Sea. The depth contours by which assemblages were separated in our analysis are the 30-m, 50-m, 70-m and 100-m contours. As shown in this paper, the zone deeper than $100 \mathrm{~m}$ is inhabited by cold water species; the one shallower than $50 \mathrm{~m}$ is inhabited by warm water species; and the intermediate zone between 50 and $100 \mathrm{~m}$ depth is inhabited by cold as well as warm water species.

The classification of assemblages in this paper shows that there are more than two depth contours structuring the benthos and that the $70-\mathrm{m}$ and $30-\mathrm{m}$ contours are more important for the distribution of assemblages than the 50-m depth contour. The separation of the fauna into a northern and a southern one along the 70-m contour might be a result of the current pattern in the North Sea. Most of the Fair Isle-Orkney inflow of Atlantic water moves eastwards at about $57^{\circ} 30^{\prime} \mathrm{N}$ and only part of it travels southwards down the coast of England (Lee, 1980). The shallow southern North Sea is, in contrast to the deeper northern areas, influenced by the English Channel inflow which extends up to the Dogger Bank. The northern North Sea and part of the central North Sea is therefore influenced by a different type of water than the rest of the North Sea. Among plankton communities those of the northern and central North Sea are similar but neritic species are more numerous in the central North Sea (Adams, 1987). The distribution of larger epifauna has been shown to be likewise determined by these two different water masses (Frauenheim et al., 1989). The epifauna north of the Dogger Bank is different from the one in the southern North Sea.

Another factor determining the distribution of assemblages is the annual variation of temperature in bottom waters. Large areas of the southern North Sea are not stratified during most of the year (Tomczak and Goedecke, 1964) and therefore the summer temperature of bottom waters is high $\left(>10^{\circ} \mathrm{C}\right.$ ) (Tomczak and Goedecke, 1962), while in the stratified areas north of the Dogger Bank summer temperatures are less than $7^{\circ} \mathrm{C}$. In winter the southern North Sea is colder $\left(4^{\circ} \mathrm{C}\right)$ than the rest of the North Sea $\left(5-7^{\circ} \mathrm{C}\right)$. These differences in temperature north and south of the Dogger Bank might explain why cold water species do not go further south than the Dogger Bank. The explanation for why warm water species are not found below 70-100 $\mathrm{m}$ depth, although they survive the cold summer temperatures in the central North Sea, might lie in the general current pattern.

A third factor which may cause the differences among the assemblages is the availability of food. Large stocks of copepods develop only in the northern North Sea. They consume the summer production of phytoplankton (Fransz and Gieskes, 1984). The faecal pellets do not reach the deep water, being recycled higher in the water column (Krause, 1981) so limiting this source of food to the benthos in the summer months. This could explain the low biomass of infauna in the northern North Sea. Further south, main parts of the phytoplankton production reach the bottom, resulting in better food supply to the benthos, especially in summer months. Buchanan (1963) has stated already that a relevant ecological factor for benthic assemblages can be found in the quality of the suspended matter together with the speed and nature of its flow over the bottom.

The separation of benthic assemblages along the $30-\mathrm{m}$ depth contour can be caused by several environmental factors. No thermal stratification of the water column develops in summer months in the shallow coastal areas, whereas below $30 \mathrm{~m}$ depth a stratification may develop (Tomczak and Goedecke, 1964). Strong tidal currents exist in the shallow coastal zones and the wave action reaches the bottom, stirring up fine particles of sediment and organic matter. These areas therefore consist of sand and gravel, while in areas of 30 to $50 \mathrm{~m}$ depth the deposit usually consists of muddy fine sand. As a consequence of these environmental differences, the food availability must be different, resulting in different feeding types.

Besides depth, the sediment structures the distribution of the assemblages. Depth and sediment are interrelated since coarser sediments usually occur in shallower areas. As shown in this paper, several species occur on all types of sediment while other species are restricted to sediments of a certain grain size. This holds for all groups: polychaetes, molluscs, echinoderms and crustaceans. Kirkegaard (1969) found the sediment to be more important than the depth for determining the distribution of polychaetes in the North Sea. Also, in the German Bight associations are mostly tied to different types of bottom (Salzwedel et al., 1985). The bottom fauna communities off the coast of Northumberland, on the other hand, are poorly correlated with the texture of the bottom sediments (Buchanan, 1963). In the latter area the sediment conditions of the various communities overlap broadly 
and different communities are found in apparently similar sediments. The present results show that northern and southern assemblages meet in the area off the coast of Northumberland. Since these assemblages seem to be determined by different water masses, the sediment might be of less importance in structuring the assemblages. In the German Bight water masses are more uniform and therefore the sediment becomes the structuring factor.

The classification of the benthic fauna into assemblages is a matter of scale. The analysis of the benthic assemblages, shown here, has been carried out on a broad scale and shows the differences in species composition within the large area of the North Sea. If the benthic infauna of certain parts of the North Sea is analysed, as has been done for the area off the coast of Northumberland (Buchanan, 1963), the Fladenground (McIntyre, 1961), the German Bight (Salzwedel et al., 1985), the northern North Sea (Eleftheriou and Basford, 1989), the vicinity of the Ekofisk and Eldfisk oilfields (Gray et al., 1990), or even for a limited area within the area covered by the NSBS (Künitzer, 1990; Duineveld et al., 1991), the eight assemblages described in this paper are divided further. The question is in how much detail we would like to look at small scale distribution.

Regarding the broad scale of the whole North Sea, assemblages of other benthic groups like the meiofauna (Huys et al., 1990) and the epifauna (Dyer et al., 1983 and Frauenheim et al., 1989) are structured and grouped within about the same areas as the macrobenthic infauna assemblages. The macrobenthic assemblages seem to reflect general environmental differences within the North Sea which should be taken into account when assessing the effects of anthropogenic changes in the North Sea. These changes might differ between the various assemblages.

\section{References}

Adams, J. A. 1987. The primary ecological sub-division of the North Sea: some aspects of their plankton communities. In Developments in fisheries research in Scotland. Ed. by R. S. Bailey and B. B. Parrish. Fishing News, London.

Anonymous, 1986. Fifth report of the Benthos Ecology Working Groups. ICES 1986/C: 27.

Buchanan, J. B. 1963. The bottom fauna communities and their sediment relationship off the coast of Northumberland. Oikos, 14: $154-175$

Buchanan, J. B., and Moore, J. J. 1986. A broad review of variability and persistence in the Northumberland benthic fauna1971-85. Journal of the Marine Biological Association of the UK, 66: 641-657.

Chambers, S. 1985. Polychaetes from Scottish waters. Part 2. Families Aphroditidae, Sigalionidae and Polyodontidae. Royal Scottish Museum Studies.

Duineveld, G. C. A., Künitzer, A., Niermann, U., DeWilde, P. A. W. J., and Gray, J. S. 1991. The macrobenthos of the North Sea. Netherlands Journal of Sea Research, 28: 53-65.

Eleftheriou, A., and Basford, D. J. 1989. The macrobenthic infauna of the offshore northern North Sea. Journal of the Marine Biological Association of the UK, 69: 123-143.
Fauvel, P. 1923. Polychetes errantes. Fauna de France, 5: 488.

Fransz, H. G., and Gieskes, W. N. C. 1984. The imbalance of phytoplankton and copepods in the North Sea. Rapports et Procès-Verbaux des Réunions du Conseil International pour l'Exploration de la Mer, 183: 218-225.

Frauenheim, K., Neumann, V., Thiel, H., and Türkay, M. 1989. The distribution of the larger epifauna during summer and winter in the North Sea and its suitability for environmental monitoring. Senkenbergiana Marit. 20: 101-118.

Glemarec, M. 1973. The benthic communities of the European Continental North Atlantic shelf. Oceanography and Marine Biology Annual Reviews, 11: 263-289.

Gray, J. S., Clarke, K. R., Warwick, R. M., and Hobbs, G. 1990. Detection of initial effects of pollution on marine benthos: an example from the Ekofisk and Eldfisk oilfields, North Sea. Marine Ecology Progress Series, 66: 285-299.

Hartmann-Schröder, G. 1971. Annelida, Borstenwürmer Polychaeta. In Die Tierwelt Deutschlands, Ed. by R. Dahl.

Heip, C., and Niermann, U. (Eds) 1989. Taxonomy of North Sea benthos. Proceedings of a workshop organized in Helgoland, 8-12 February 1988. Delta Institute, Yerseke.

Hill, M. O. 1979. TWINSPAN-a Fortran program for arranging multivariate data in an ordered two-way table by classification of the individuals and attributes. Ecology and Systematics, Cornell University, New York.

Howson, C. M. (Ed.) 1987. Directory of the British marine fauna and flora. A coded checklist of the marine fauna and flora of the British Isles and its surrounding seas. Marine Conservation Society.

Huys, R., Heip, C. H. R., Herman, P. M. J., and Soetaert, K. 1990. The meiobenthos of the North Sea: preliminary results of the North Sea Benthos Survey. ICES CM 1990/Mini: 8.

ICES. 1986. Fifth report of the Benthos Ecology Working Group. ICES CM 1986/L: 27.

Jones, N. S. 1950. Marine bottom communities. Biological Reviews, 25: 283-313.

Josefson, A. B. 1981. Persistence and structure of two deep macrobenthic communities in the Skagerrak (west coast of Sweden). Journal of Experimental Marine Biology and Ecology, 50: 63-97.

Kingston, P. F., and Rachor, E. 1982. North Sea level bottom communities. ICES CM 1982/L: 41 .

Kirkegaard, J. B. 1969. A quantitative investigation of the central North Sea polychaeta. Spolia Zoologica Musei Hauniensis, 29: 1-285.

Krause, M. 1981. Vertical distribution of faecal pellets during FLEX '76. Helgoländer Meeresuntersuchungen, 34: 313-337.

Kröncke I. 1990. Macrofauna standing stock of the Dogger Bank. A comparison: II. 1951-1952 versus 1985-1987. Are changes in the community of the northeastern part of the Dogger Bank due to environmental changes? Netherlands Journal of Sea Research, 25: 189-198.

Künitzer, A. 1990. The infauna and epifauna of the central North Sea. Meeresforschung, 33: 23-37.

Lee, A. J. 1980. North Sea: physical oceanography. In The north-west European shelf seas: The sea bed and the sea in motion. II. Physical and chemical oceanography and physical resources, pp. 467-493. Ed. by F. T. Banner, M. B. Collins and K. S. Massie, Elsevier, Amsterdam.

McIntyre, A. D. 1961. Quantitative differences in the fauna of boreal mud associations. Journal of the Marine Biological Association of the United Kingdom, 41: 599-616.

Petersen, C. G. J. 1914. Valuation of the sea. II. The animal communities of the sea bottom and their importance for marine zoogeography. Rep. Dan. Biol. Stn. 21: $1-44$. 
Petersen, G. H. 1977. The density, biomass and origin of the bivalves of the central North Sea. Meddelelser fra Danmarks Fiskeri- og Havundersøgelser, 7: 221-273.

Rumohr, H., Brey, T., and Ankar, S. 1987. A compilation of biometric conversation factors for benthic invertebrates in the Baltic Sea. Baltic Marine Biologists Publication, 9: $1-56$.

Salzwedel, H., Rachor, E., and Gerdes, D. 1985. Benthic macrofauna communities in the German Bight. Veräffentlichungen des Instituto für Meeresforschung, Bremerhaven, 20: $199-267$.
Tomczak, G., and Goedecke, E. 1962. Monatskarten der Temperatur der Nordsee, dargestellt für verschiedene Tiefenhorizonte. Deutsche Hydrographische Zeitschrift, Ergänzungsheft, $\mathrm{B}\left(4^{\circ}\right)$, No.7.

Tomczak, G., and Goedecke, E. 1964. Die thermische Schichtung der Nordsee auf Grund des mittleren Jahresgangs der Temperatur in $1 / 2^{\circ}$ - und $1^{\circ}$-Feldern. Deutsche Hydrographische Zeitschrift, Ergänzungsheft, $\mathrm{B}\left(4^{\circ}\right)$, No.8.

Ursin, E. 1960. A quantitative investigation of the echinoderm fauna of the central North Sea. Meddelelser fra Danmarks Fiskeri- og Havundersøgelser, 2: 1-204. 
